\title{
Penguatan ideologi Pancasila di kalangan peserta didik MTsN I Pati
}

\author{
Siti Alfiatun \\ MTs Negeri I Pati \\ sitialfigabus@gmail.com \\ korespondensi penulis
}

\begin{abstract}
ABSTRAK
Sebuah ideologi, selain memiliki aspek ideal berupa ide, pemikiran, dan nilai yang dianggap dapat diterima, ideologi juga harus memiliki norma yang eksplisit. Sebab, sebuah doktrin harus bisa diwujudkan dalam kehidupan nyata. Era reformasi telah melahirkan perubahan signifikan yang terjadi dalam pengalaman sosial, ekonomi, politik, bahkan termasuk dalam dunia pendidikan. Pancasila mulai tergeser ketika terjadi krisis yang mengakibatkan keterpurukan hampir di semua bidang kehidupan. Nilai-nilai Pancasila yang perlu diteruskan secara turun-temurun dapat melalui pendidikan PPKn di sekolah. Pengetahuan tentang Pancasila dalam kurikulum saat ini menjadi mata pelajaran Pendidikan dan Kewarganegaraan Pancasila di sekolah. Pendidikan dan Kewarganegaraan Pancasila merupakan salah satu cara untuk menanamkan akhlak dan wawasan pribadi dalam kehidupan berbangsa dan bernegara. Permasalahan yang diangkat dalam artikel ini adalah seberapa jauh tingkat pengetahuan dan pemahaman Ideologi Pancasila dikalangan mahasiswa bagaimana solusi untuk memperkuat Ideologi Pancasila dikalangan mahasiswa. Dalam penelitian ini, data primer diperoleh peneliti melalui kuesioner atau kuesioner. Kuesioner atau kuesioner yang digunakan didasarkan pada cara menjawab kuesioner atau kuesioner tertutup. Hasil penelitian menunjukkan bahwa hampir semua responden mengamalkan nilai-nilai Pancasila secara signifikan.
\end{abstract}

Kata kunci: ideologi, Pancasila, nilai, siswa, penguatan

\section{ABSTRACT}

An ideology, in addition to having ideal aspects in the form of ideas, thoughts, and values that are considered acceptable, ideology must have explicit norms. This is because a doctrine must be able to be realized in real life. The era of reform has given birth to significant changes that occur in social, economic, political experience, and even including in the world of education. Pancasila began to be displaced when there was a crisis that resulted in a downturn in almost all areas of life. Pancasila values that need to be relayed from generation to generation can be through PPKn education in schools. Knowledge about Pancasila in the curriculum is now a subject of Pancasila Education and Citizenship in schools. Pancasila Education and Citizenship is one way to instill moral and insightful individuals in the life of the nation and state. The problem raised in this article is how much the level of knowledge and understanding of the Pancasila Ideology among students how is the solution to reinforce the Pancasila Ideology among students. In this study, primary data obtained by researchers through a questionnaire or questionnaire. The questionnaire or questionnaire used is based on the way to answer the questionnaire or a closed questionnaire. From the research, the results show that almost all respondents practice the value of Pancasila values significantly.

Keywords : Pancasila, values, students, strengthening

Copyright (C2020 Universitas Ahmad Dahlan

\section{PENDAHULUAN}

Bangsa Indonesia merupakan salah satu dari berbagai bangsa di dunia yang mempunyai sejarah serta prinsip atau ideologi dalam kehidupan yang berbeda dengan bangsa-bangsa lainnya. Pancasila dipilih sebagai ideologi bangsa Indonesia karena nilai- nilainya digali dari harta kekayaan rohani, moral, dan budaya masyarakat Indonesia sendiri. Pancasila memiliki fungsi dan kedudukan yang penting dalam negara Indonesia yaitu sebagai jati diri bangsa Indonesia, sebagai ideologi bangsa dan negara Indonesia, sebagai dasar filsafat negara, serta sebagai asas persatuan bangsa Indonesia.

Fungsi dan kedudukan Pancasila tersebut mulai terancam di era reformasi yang ditandai dengan runtuhnya rezim Orde Baru dan adanya krisis ekonomi yang mengakibatkan keterpurukan hampir di semua bidang kehidupan. Kepercayaan terhadap Pancasila mulai pudar. Era reformasi telah banyak melahirkan perubahan- perubahan signifikan yang terjadi dalam kehidupan sosial, ekonomi, politik bahkan termasuk dalam dunia pendidikan. Pancasila mulai tergeser saat terjadi 
krisis yang mengakibatkan keterpurukan di hampir semua bidang kehidupan.

Saat ini setelah reformasi terjadi selama 22 tahun kondisi bangsa Indonesia belum sepenuhnya pulih dan stabil. Kondisi perekonomian warga Indonesia bisa dikatakan masih di bawah standar. Angka pengangguran yang cukup tinggi penyebab salah satunya. Selain itu sistem pendidikan yang selalu berganti-ganti setiap ada pergantian Menteri Pendidikan semakin memperparah kondisi bangsa Indonesia. Sehingga bangsa Indonesia masih termasuk negara berkembang.

Sumber daya manusia di Indonesia yang masih kurang juga termasuk salah satu penyebab belum majunya bangsa Indonesia. Pada abad 21 ini arus globalisasi semakin menggila. Mulai dari barang keperluan sehari-hari sampai berbagai ideologi lain bebas masuk di Indonesia. Pesatnya perkembangan teknologi juga termasuk salah satu faktor pendorongnya. Sehingga di abad 21 ini manusia dituntut untuk tidak hanya menguasai satu bidang keahlian melainkan dua atau tiga keahlian sekaligus. Sudah saatnya rakyat Indonesia bangun dari ketertinggalan tersebut. Sudah saatnya ideologi Pancasila benar-benar diaplikasikan secara nyata dalam kehidupan sehari-hari di Indonesia. Karena Ideologi Pancasila begitu strategis kedudukannya di Indonesia ini.

Mengingat bahwa begitu strategisnya kedudukan Pancasila sebagai dasar pemersatu bangsa Indonesia, maka Pancasila harus tetap dipertahankan dan dilestarikan dengan melalui revitalisasi dan aktualisasi dalam kehidupan bermasyarakat, berbangsa dan bernegara. Agar Pancasila tetap vital dan aktual sebagai pemersatu bangsa maka nilai-nilai Pancasila perlu diestafetkan dari generasi ke generasi melalui proses pendidikan.

Nilai-nilai Pancasila yang perlu diestafetkan dari generasi ke generasi tersebut dapat melalui pendidikan PPKn. Pendidikan tentang Pancasila dalam kurikulum sekarang merupakan mata pelajaran Pendidikan Pancasila dan Kewarganegaraan di sekolah.

PPKn merupakan salah satu cara untuk menanamkan pribadi yang bermoral dan berwawasan luas dalam kehidupan berbangsa dan bernegara. Oleh karena itu, PPKn perlu diberikan disetiap jenjang pendidikan mulai dari tingkat dasar, menengah hingga perguruan tinggi melalui pendidikan Pancasila.

Pendidikan Pancasila sebagai pendidikan kebangsaan berangkat dari keyakinan bahwa Pancasila sebagai dasar negara, falsafah negara
Indonesia tetap mengandung nilai dasar yang relevan dengan proses kehidupan dan perkembangan dalam berbangsa dan bernegara. Pancasila memiliki landasan eksistensial yang kokoh, baik secara filosofis, yuridis, maupun sosiologis.

Landasan-landasan tersebut seharusnya semakin memperkokoh keberadaan Pancasila di Indonesia. Akan tetapi fakta justru berkata sebaliknya. Saat ini kekuatan Pancasila sebagai ideologi dan pandangan hidup bangsa mulai melemah, salah satunya terjadi pada kelompok peserta didik. Beberapa tahun terakhir menunjukkan makin minimnya minat peserta didik terhadap Pancasila. Anak Bangsa yang diharapkan menjadi penerus kepemimpinan bangsa ternyata abai dengan Pancasila. Fenomena menurunnya pengetahuan dan pemahaman terhadap Pancasila di kalangan peserta didik tersebut tidak hanya menjadi sebuah wacana yang biasa, namun perlu ditelusuri dan ditindaklanjuti apa penyebabnya. Beragam faktor yang menjadi penyebab menurunnya pengetahuan dan pemahaman terhadap Pancasila di kalangan peserta didik harus digali dan dicari solusi terbaik untuk kembali menguatkan pengetahuan dan pemahaman ideologi Pancasila di kalangan peserta didik.

Berdasarkan latar belakang yang telah dikemukakan diatas, maka dapat dirumuskan beberapa permasalahan sebagai berikut (1) Seberapa besar tingkat pengetahuan dan pemahaman Ideologi Pancasila di kalangan peserta didik?, dan (2) Bagaimana solusi untuk menguatkan kembali Ideologi Pancasila di kalangan peserta didik?

\section{METODE}

Dalam penelitian ini penulis mengambil sampel penelitian di MTs Negeri I Pati Kelas 7C sebanyak 32 peserta didik yang terdiri dari 15 peserta didik laki-laki dan 17 peserta didik perempuan, penelitian ini dilakukan dalam kurun waktu antara Agustus hingga Oktober 2019.

Jenis data yang digunakan peneliti dalam penelitian ini adalah berdasarkan cara memperoleh yaitu data primer. Data Primer adalah data yang didapatkan langsung dari responden penelitian. Data primer diambil langsung dari responden atau target pengamatan. Data primer dapat diperoleh dari hasil wawancara, angket dan observasi.

Dalam penelitian ini, data primer diperoleh peneliti melalui angket atau kuesioner. Angket atau kuesioner yang digunakan adalah berdasarkan cara menjawab yaitu angket atau 
kuesioner tertutup. Angket ini dibagikan kepada 31 responden. Sehingga sampel yang digunakan sebanyak 31 sampel.

Menurut Patton, 1980 (Moleong, 2011) analisis data adalah proses mengatur urutan data, mengorganisasikanya ke dalam suatu pola, kategori, dan satuan uraian dasar.

Teknik analisis data yang digunakan peneliti dalam penelitian ini adalah teknik analisis kuantitatif deskriptif. Teknik analisis ini disebut juga teknik analisis statistk deskriptif. Analisis statistik deskriptif berfungsi mengklasifikasikan suatu data variable berdasarkan kelompoknya masing- masing dari semula belum teratur dan mudah diinterpretasikan maksudnya oleh orang yang membutuhkan informasi tentang keadaan variabel tersebut. Selain itu statistik deskriptif juga berfungsi menyajikan informasi sedemikian rupa, sehingga data yang dihasilkan dari penelitian dapat dimanfaatkan oleh orang lain yang membutuhkan.

Ciri analisis kuantitatif adalah selalu berhubungan dengan angka, baik angka yang diperoleh dari pencacahan maupun penghitungan. Data yang telah diperoleh dari pencacahan selanjutnya diolah dan disajikan dalam bentuk yang lebih mudah dimengerti oleh pengguna data tersebut. Sajian data kuantitatif sebagai hasil analisis kuantitatif dapat berupa angka-angka maupun gambar- gambar grafik.

Analisis data dilakukan oleh penulis setelah semua data terkumpul menjadi satu. Setelah semua data terkumpul, penulis baru akan melakukan analisis. Sehingga penulis harus mengumpulkan data sebanyak-banyaknya dalam bentuk dokumen melalui media internet, seperti jurnal, artikel, dan yang lainnya.

\section{HASIL DAN PEMBAHASAN}

Untuk mendapatkan data peneliti menyebarkan kuesioner kepada 32 peserta didik. Berikut ini adalah penjelasan dari data tersebut.

Pada pernyataan pertama pada kuesioner semua peserta didik selalu melaksanakannya. Halini menunjukkan bahwa implementasi Pancasila sila pertama pada kalangan peserta didik bagus dan maksimal. Hal ini bisa membawa kebaikan bagi calon penerus bangsa menjadi pribadi yang berkarakter mulia dan berdedikasi tinggi terhadap negara. Dari presentase tersebut menunjukkan bahwa kalangan peserta didik sudah sepenuhnya mempunyai dan menerapkan kewajibannya kepada Tuhan Yang Maha Esa dalam kehidupan sehari-hari. Jadi penerapan
Pancasila sila pertama untuk indikator ini harus tetap dipertahankan.

Pada pernyataan kedua pada kuesioner $90 \%$ peserta didik selalu melaksanakannya. Sedangkan $10 \%$ lainnya kategori sering melakukannya. Disini seharusnya semua peserta didik bisa selalu melaksanakannya. Hal ini karena indikator tersebut merupakan suatu dasar dalam menciptakan keharmonisan antarumat beragama. Dengan adanya keharmonisan tersebut tidak akan ada lagi konflik dan isu tidak

baik berkenaan dengan keberagaman agama tersebut. Jadi penerapan Pancasila sila pertama untuk indikator yang satu ini harus ditingkatkan dan dimaksimalkan lagi.

Pada pernyataan ketiga pada kuesioner 55\% peserta didik selalu melakukannya. Sedangkan $45 \%$ lainnya sering melakukannya. Di sini seharusnya semua peserta didik bisa selalu melakukannya. Karena indikator ini menunjukkan bagaimana sikap peserta didik dalam menghadapi hari yang baru. Apabila peserta didik selalu melakukannya akan membawa kebaikan pada dirinya sendiri. Karena segala sesuatu yang dimulai dengan doa hasilnya akan baik juga. Jadi penerapan Pancasila sila pertama untuk indikator ini harus ditingkatkan dan dimaksimalkan lagi.

Pada pernyataan keempat pada kuesioner $55 \%$ peserta didik sering melakukannya. Sedangkan $\quad 45 \%$ lainnya kadng-kadang melakukannya. Seharusnya semua peserta didik bisa selalu melakukannya. Karena indikator ini menunjukkan seberapa besar rasa peduli kita terhadap sesama khususnya rasa kemanusiaan. Besar kecilnya rasa kemanusiaan dalam diri kita masing- masing akan menentukan seberapa aktif atau tidaknya kita dalam kegiatan kemanusiaan. Dari presentase tersebut menunjukkan bahwa kalangan peserta didik belum sepenuhnya mempunyai dan menerapkan rasa kemanusiaannya dalam tindakan nyata. Jadi penerapan Pancasila sila kedua untuk indikator ini harus ditingkatkan dan dimaksimalkan lagi.

Pada pernyataan kelima pada kuesioner 30\% peserta didik selalu melakukannya. 35\% lainnya sering melakukannya serta $35 \%$ lainnya kadangkadang saja melakukannya. Seharusnya semua peserta didik bisa selalu melakukannya. Karena indikator ini menunjukkan seberapa besar rasa keberanian kita untuk membela kebenaran dan keadilan. Besar kecilnya rasa keberanian ini menentukan banyak tidaknya orang yang tidak bersalah akan menjadi tersangka. Dari presentase tersebut menunjukkan bahwa kalangan pesera didik belum sepenuhnya mempunyai dan 
menerapkan rasa keberanian dalam tindakan nyata. Jadi penerapan Pancasila sila kedua untuk indikator ini harus ditingkatkan dan dimaksimalkan lagi.

Pada pernyataan keenam pada kuesioner $85 \%$ peserta didik selalu melakukannya. Sedangkan $10 \%$ lainnya sering melakukannya dan 5\% lainnya kadang-kadang saja dalam melakukannya. Seharusnya semua peserta didik bisa melakukannya. Karena indikator ini merupakan dasar bagi kita apabila kita ingin dihargai dan dihormati orang lain kita juga harus menghargai dan menghormati orang lain juga. Ini seperti sebuah kegiatan timbal balik. Apabila satu pihak tidak mau melakukannya maka pihak yang lain juga tidak akan melakukannya. Hal ini apabila dibiarkan berlarut-larut akan menumbulkan suatu masalah. Dari presentase tersebut menunjukkan bahwa kalangan peserta didik belum sepenuhnya mempunyai dan menerapkan rasa saling menghormati dan menghargai dengan sesama dalam kehidupan sehari-hari. Jadi penerapan Pancasila sila keempat untuk indikator ini harus ditingkatkan dan dimaksimalkan lagi.

Pada pernyataan ketujuh pada kuesioner $85 \%$ peserta didik selalu melakukannya. Sedangkan 10\% lainnya sering melakukannya dan $5 \%$ lainnya kadang-kadang saja melakukannya. Seharusnya semua peserta didik bisa melakukannya. Karena indikator ini merupakan acuan dasar bagi kita untuk menciptakan keselaran dan keharmonisan dalam kehidupan. Setiap manusia mempunyai hak untuk diakui dan diperlakukan sesuai dengan harkat dan martabatnya sebagai makhluk Tuhan Yang Maha Esa. Sehingga antara manusia yang satu dengan yang lain harus saling memberikan pengakuan dan perlakuan tersebut supaya HAM bisa ditegakkan dengan sebaik-baiknya. Dari presentase tersebut menunjukkan bahwa kalangan belum sepenuhnya mempunyai dan menerapkan rasa untuk saling menghormati dan menghargai dalam kehidupan sehari-hari. Jadi penerapan Pancasila sila kedua untuk indikator ini harus ditingkatkan dan dimaksimalkan lagi.

Pada pernyataan kedelapan pada kuesioner $60 \%$ peserta didik selalu melakukannya. Sedangkan 30\% lainnya sering melakukannya serta $10 \%$ lainnya kadang-kadang saja melakukannya. Seharusnya semua peserta didik bisa selalu melakukannya. Karena indikator ini merupakan acuan bagi kita untuk melakukan suatu perundingan yang hasilnya nanti akan sesuai dengan tujuan kegiatan sehingga bisa diterima dengan ikhlas oleh semua anggota. Dengan begitu keputusan yang dihasilkan akan dijalankan dengan senang hati oleh anggota karena keputusan tersebut merupakan hasil kesepakatan bersama yang tidak akan merugikan pihak manapun. Dari presentase tersebut menunjukkan bahwa kalangan peserta didik belum sepenuhnya mempunyai atau menerapkan semangat musyawarah untuk menentukan keputusan dalam kehidupan seharih- hari. Jadi penerapan Pancasila sila keempat untuk indikator ini harus ditingkatkan dan dimaksimalkan lagi.

Pada pernyataan kesembilan pada kuesioner $10 \%$ peserta didik sering melakukannya. Sedangkan $\quad 75 \%$ lainnya kadang-kadang melakukannya dan 15\% lainnya tidak pernah melakukannya. Seharusnya semua peserta didik bisa untuk tidak pernah melakukannya. Karena tindakan tersebut tidak akan memberikan kebaikan untuk Indonesia akan tetapi sebaliknya. Sehingga mulai saat ini kita harus bersama-sama saling bekerja sama satu sama lain untuk melakuakan kreasi dan inovasi berbagai produk dalam negeri supaya bisa mempunyai kualitas yang sama atau melebihi barang luar negeri. Dengan begitu angka impor yang dilakukan oleh Indonesia tidak akan naik secara terus- menerus setiap tahunnya. Dari presentase tersebut menunjukkan bahwa kalangan peserta didik belum sepenuhnya menerapkan rasa mencintai dan memakai produk dalam negeri dalam kehidupan sehari- hari. Jadi penerapan Pancasila sila ketiga untuk indikator ini harus ditingkatkan dan dimaksimalkan lagi.

Pada pernyataan kesepuluh pada kuesioner $90 \%$ peserta didik selalu melakukannya. Sedangkan 10\% lainnya sering melakukannya. Seharusnya semua peserta didik bisa melakukannya. Karena ini merupakan acuan dasar bagi kita untuk menerapkan rasa nasionalisme dalam diri kita masing-masing. Dimulai dengan adanya rasa bangga lamakelamaan akan berkembang menjadi rasa cinta dan selalu siap berkorban untuk kepentingan bangsa dan negara. Dari presentase tersebut menunjukkan bahwa kalangan responden belum sepenuhnya mempunyai rasa nasionalisme yang kuat dalam pribadi masing-masing. Jadi penerapan Pancasila sila ketiga untuk indikator ini harus ditingkatkan dan dimaksimalkan lagi.

Pada pernyataan kesebelas pada kuesioner $40 \%$ peserta didik selalu melakukannya. Sedangkan 50\% lainnya sering melakukannya serta 10\% lainnya kadang-kadang melakukannya. Seharusnya semua peserta didik bisa selalu melakukannya. Karena indikator ini merupakan suatu acuan dasar bagi kita untuk membentuk pribadi kita menjadi pribadi yang kuat dan tangguh untuk mencapai kemenangan. Pada 
nantinya karakter- karakter seperti itulah yang akan membawa perubahan-perubahan yang besar bagi negeri. Dari presentase tersebut menunjukkan bahwa kalangan peserta didik belum sepenuhnya mempunyai dan menerapkan rasa pantang menyerah dan kerja keras dalam kehidupan sehari-hari. Jadi penerapan Pancasila sila kelima untuk indikator ini harus ditingkatkan dan dimaksimalkan lagi.

Pada pernyataan kedua belas pada kuesioner $70 \%$ peserta didik selalu melakukannya. Sedangkan 30\% lainnya sering melakukannya. Seharusnya semua peserta didik bisa selalu melakukannya. Karena indikator ini merupakan acuan dasar bagi kita untuk menciptakan rasa menghormati terhadap apapun dan siapapun. Apabila kita bisa menghormati setiap keputusan yang telah dimusyawarahkan baik itu hal kecil sekalipun nantinya kita juga akan dengan mudah menghormati keputusan musyawarah mengenai hal yang besar sekalipun yang menyangkut kepentingan berbagai pihak. Dari presentase tersebut menunjukkan bahwa kalangan peserta didik belum sepenuhnya mempunyai dan menerapkan rasa menghormati keputusan musyawarah dalam kehidupan sehari-hari. Jadi penerapan Pancasila sila keempat untuk indikator ini harus ditingkatkan dan dimaksimalkan lagi.

Pada pernyataan ketigabelas pada kuesioner $25 \%$ peserta didik selalu melakukannya. Sedangkan 50\% lainnya sering melakukannya serta $25 \%$ lainnya kadang-kadang saja melakukannya.Seharusnya semua peserta didik bisa melakukannya. Karena ini merupakan acuan dasar bagi kita untk menciptakan sikap dan karakter tanggung jawab terhadap diri sendiri dan orang-orang di sekitar kita. Tanggung jawab merupakan hal besar yang bisa dimulai dari diri sendiri. Apabila kita sudah bisa bertanggung jawab terhadap diri sendiri maka kita juga akan bisa bertanggung jawab kepada siapapun. Karena sebenarnya yang paling berat adalah tanggung jawab terhadap diri sendiri. Dari presentase tersebut menunjukkan bahwa kalangan peserta didik belum sepenuhnya mempunyai dan menerapkan rasa tanggung jawab dalam kehidupan sehari-hari. Jadi penerapan Pancasila sila kelima untuk indikator ini harus ditingkatkan dan dimaksimalkan lagi.

Pada pernyataan keempat belas pada kuesioner $10 \%$ peserta didik selalu melakukannya. Sedangkan $60 \%$ lainnya sering melakukannya serta 30\% lainnya kadang-kadang melakukannya. Seharusnya semua peserta didik bisa selalu melakukannya. Karena indikator ini merupakan dasar bagi kita untuk mengetahui seberapa besar rasa patriotisme kita. Disini besar kecilnya rasa patriotisme setiap individu akan berperan besar bagi keberlangsungan suatu negara. Apabila semua individu dalam suatu negara mempunyai rasa patriotisme yang sama besarnya maka negara tersebut akan menjadi negara yang kuat. Negara yang tidak mudah dijajah oleh berbagai hal baru yang bertentangan dengan identitas bangsa. Dari presentase tersebut menunjukkan bahwa kalangan responden belum sepenuhnya mempunyai dan menerapkan rasa patriotisme dalam tindakan nyata. Jadi penerapan Pancasila sila ketiga untuk indikator ini harus ditingkatkan dan dimaksimalkan lagi.

Pada pernyataan kelima belas pada kuesioner $25 \%$ peserta didik selalu melakukannya. Sedangkan $60 \%$ lainnya sering melakukannya serta 15\% lainnya kadang-kadang saja melakukannya. Seharusnya semua peserta didik bisa melakukannya. Karena indikator ini merupakan dasar bagi kita untuk belajar jujur dengan menghargai hasil karya orang lain dan tidak melakukan plagiasi. Dengan menanamkan sikap jujur pada diri sendiri, nantinya kita akan selalu terbiasa untuk jujur kepada siapapun mengenai berbagai kebenaran dan keadilan. Sehingga nantinya para pendusta di muka bumi ini jumlahnya akan berkurang dan semakin berkurang hingga tidak ada sama sekali. Dari presentase tersebut menunjukkan bahwa kalangan responden belum sepenuhnya mempunyai dan menerapkan sikap jujur dalam kehidupan sehari-hari. Jadi penerapan Pancasila sila kelima untuk indikator ini harus ditingkatkan dan dimaksimalkan lagi.

Pada pernyataan keenam belas pada kuesioner $5 \%$ peserta didik selalu melakukannya. Sedangkan 15\% lainnya sering melakukannya, $55 \%$ lainnya kadang-kadang melakukannya serta $25 \%$ lainnya tidak pernah melakukannya. Presentase ini sangat tidak bagus. Karena indikator ini merupakan dasar bagi kita untuk aktif dalam organisasi yang bisa dimulai dari kegiatan OSIS, Pramuka, PMR dan kegiatan lainnya yang ada di madrasah. Karena keaktifan tersebut akan memberikan dampak yang besar bagi kehidupan peserta didik selama sekolah. Selain itu, keaktifan ini juga akan menentukan banyak sedikitnya teman yang dimiliki oleh peserta didik. Dari presentase tersebut menunjukkan bahwa kalangan peserta didik belum sepenuhnya mempunyai dan menerapkan sikap aktif berorganisasi dalam kehidupan seharihari. Jadi penerapan Pancasila sila kedua untuk indikator ini harus ditingkatkan dan dimaksimalkan lagi.

Pada pernyataan ketujuh belas pada kuesioner bahwa $5 \%$ peserta didik selalu 
melakukannya. Sedangkan 35\% lainnya sering melakukannya, 40\% lainnya kadang-kadang saja serta $20 \%$

lainnya tidak pernah melakukannya. Presentase ini kurang bagus. Karena masih rendah sekali presentasenya. Indikator ini bisa menjadi acuan dasar bagi kita untuk menentukan semangat tidaknya peserta didik berorganisasi serta menentukan juga keaktifan peserta didik di luar madrasah (dalam organisasi). Apabila peserta didik tidak mempunyai keinginan untuk berorganisasi itu sangat berbahaya. Karena berbagai pengalaman baru tidak akan mereka dapatkan. Seperti berbagai pengalaman dalam kepanitiaan, pengalaman dalam berbagai kegiatan, serta berbagai pengalaman lainnya. Dari presentase tersebut menunjukkan bahwa kalangan peserta didik belum sepenuhnya mempunyai dan menerapkan sikap aktif dan semangat berorganisasi dalam kehidupan seharihari. Jadi penerapan Pancasila sila kedua untuk indikator ini harus ditingkatkan dan dimaksimalkan lagi.

Pada pernyataan kedelapan belas pada kuesioner $30 \%$ peserta didik selalu melakukannya. Sedangkan 55\% lainnya sering melakukannya serta 15\% lainnya kadang-kadang saja melakukannya. Presentase ini bagus. Karena pada dasarnya sudah $85 \%$ peserta didik yang melakukannya walaupun dengan intensitas yang berbeda. Indikator ini bisa menjadi acuan bagi kita seberapa rajin tidaknya peserta didik dalam melaksanakan kewajibannya kepada Tuhan Yang Maha Esa. Sikap ini penting karena menjadi dasar keyakinan dalam beragama dari masingmasing individu. Dari presentase tersebut menunjukkan bahwa kalangan peserta didik belum sepenuhnya mempunyai dan menerapkan sikap rajin dalam melaksanakan kewajibannya kepada Tuhan Yang Maha Esa dalam kehidupan sehari-hari. Jadi penerapan Pancasila sila pertama untuk indikator ini harus ditingkatkan dan dimaksimalkan lagi.

Pada pernyataan kesembilan belas pada kuesioner $65 \%$ peserta didik selalu melakukannya. Sedangkan 25\% lainnya sering melakukannya, 5\% lainnya kadang-kadang saja, serta $5 \%$ lainnya tidak pernah dalam melakukannya. Presentase ini bagus. Karena hampir semua peserta didik melakukannya walaupun dengan intensitas yang berbeda. Indikator ini menjadi dasar bagi kita untuk belajar menghormati berbagai keragaman yang ada di Indonesia, salah satunya dalam berteman. Ketika peserta didik sudah duduk di bangku madrasah stanawiyah peserta didik akan mengenal teman dari berbagai desa. Sehingga peserta didik tidak boleh melakukan diskriminasi atau memilih- milih dalam berteman. Karena semuanya mempunyai hak yang sama untuk dijadikan teman dalam kebaikan. Dari presentase tersebut menunjukkan bahwa kalangan responden belum sepenuhnya mempunyai dan menerapkan sikap saling menghormati keberagaman antarteman dalam kehidupan sehari-hari. Jadi penerapan Pancasila sila kelima untuk indikator ini harus ditingkatkan dan dimaksimalkan lagi.

Pada pernyataan keduapuluh pada kuesioner $65 \%$ peserta didik selalu melakukannya. Sedangkan 30 lainnya sering melakukannya serta 5\% lainnya kadangkadangmelakukannya. Presentase ini bagus. Karena hampir seluruh peserta didik melakukannya walaupun dengan intensitas yang berbeda. Indikator ini menjadi dasar bagi kita untuk selalu menebar kebaikan kepada siapapun. Apabila satu manusia menebar kebaikan dan dapat menginspirasi manusia lainnya maka semua manusia akan menebar kebaikan di dunia ini. Sehingga terciptalah suatu keadaan yang nyaman dan sangat harmonis. Dari presentase tersebut menunjukkan bahwa kalangan peserta didik hampir sepenuhnya mempunyai dan menerapkan sikap berbagi dan menebar kebaikan dalam kehidupan sehari-hari. Jadi penerapan Pancasila sila kelima untuk indikator ini harus ditingkatkan dan dimaksimalkan lagi.

Adapun cara yang dapat dilakukan untuk menguatkan nilai - nilai pemahaman dan penerapan Pancasila yaitu dengan menunjukkan sikap positif terhadap Pancasila. Sikap positif terhadap Pancasila adalah perilaku yang mengharuskan kita bersikap baik terhadap Ideologi Pancasila. Contoh sikap baik yang dapat ditunjukkan sebagai berikut (1) Menerima Pancasila sebagai dasar negara dan ideologi negara, (2) Berusaha mempelajari agar memahami makna Pancasila, nilai - nilai Pancasila dan kedudukan Pancasila sebagai dasar negara, (3) Mempertahankan Pancasila agar tetap lestari, (4) Menolak segala bentuk ideologi, paham, ajaran yang bertentangan dengan Pancasila, (5) Menetapkan Pancasila dalam kehidupan berbangsa dan bernegara, (6) Kesetiaan terhadap bangsa dan negara.

\section{KESIMPULAN}

Berdasarkan penelitian yang telah dilakukan peneliti dengan membagikan kuesioner kepada peserta didik bisa diperoleh kesimpulan sebagai berikut. 
1. Tingkat pengetahuan dan pemahaman Ideologi Pancasila di kalangan peserta didik sebagai berikut:

a. Penerapan Pancasila sila pertama pada peserta didik sudah baik untuk tiga indikator, sedangkan satu indikator lainnya belum baik. Sehingga untuk ke depannya penerapan Pancasila sila pertama dalam lingkungan peserta didik harus ditingkatkan lagi supaya menjadi maksimal.

b. Penerapan Pancasila sila kedua pada peserta didik sudah baik untuk tiga indikator, sedangkan untuk dua indikator yang lainnya belum baik. Sehingga untuk ke depannya penerapan Pancasila sila kedua dalam lingkungan peserta didik harus ditingkatkan lagi supaya menjadi maksimal.

c. Penerapan Pancasila sila ketiga pada peserta didik dua indikator sudah baik, tetapi untuk satu indikator lainnya belum baik. Sehingga untuk ke depannya penerapan Pancasila sila ketiga dalam lingkungan peserta didik harus ditingkatkan lagi supaya menjadi maksimal.

d. Penerapan Pancasila sila keempat pada peserta didik semua indikator sebanyak tiga indikator sudah baik. Sehingga untuk ke depannya penerapan Pancasila sila keempat dalam lingkungan peserta didik harus ditingkatkan lagi supaya menjadi maksimal.

e. Penerapan Pancasila sila kelima pada peserta didik semua indikator sebanyak lima indikator sudah baik. Sehingga untuk ke depannya penerapan Pancasila sila kelima dalam lingkungan peserta didik harus ditingkatkan lagi supaya menjadi maksimal.

2. Solusi yang dapat dilakukan untuk menguatkan kembali Ideologi Pancasila di kalangan peserta didik yaitu dengan menunjukkan sikap positif terhadap
Pancasila yang dapat ditunjukkan dengan beberapa perilaku sebagai berikut.

a. Menerima Pancasila sebagai dasar negara dan ideologi negara.

b. Berusaha mempelajari agar memahami makna Pancasila, nilai - nilai Pancasila dan kedudukan Pancasila sebagai dasar negara.

c. Mempertahankan Pancasila agar tetap lestari.

d. Menolak segala bentuk ideologi, paham,ajaran yang bertentangan dengan Pancasila.

e. Menetapkan Pancasila dalam kehidupan berbangsa dan bernegara.

f. Kesetiaan terhadap bangsa dan negara.

\section{DAFTAR PUSTAKA}

Al Tin Sumartini, Asep Sutisna, 2017,Pendidikan Pancasila dan Kewarganegaraan, Jakarta: Kementerian Pendidikan dan Kebudayaan

Eddy Wibowo, Mugin dkk, 2009, Panduan Penulisan Karya Ilmiah, Semarang : Universitas Negeri Semarang

Khilda Fa'zia dkk.2018,Pendidikan Pancasila dan Kewarganegaraan kelas IX, Klaten: Intan Pariwara

Moleong,Lexy,2002,Metodologi Penelitian Kualitatif, Bandung: PT. Remaja Rosdakarya.

Pancasila, Orde Baru, dan Orde Reformasi.https://www.kompasiana.com/a liakbar12/5db85034097f36712d4a5e02/pan casila-orde-baru-orde-reformasi

Yuyus Kardiman dkk, 2016, Pendidikan Pancasila dan Kewarganegaraan kelas VII, Jakarta:Erlangga 